\title{
A Study of the Training Mode of Practical Talents of Foreign Languages in Colleges and Universities
}

\author{
Yuan Kong \\ School of Foreign Languages, Jining Medical University, Jining, China
}

\begin{abstract}
Foreign language education in China has achieved remarkable achievements in the past hundred years. At present, the development of foreign language majors in China is fast, but there are still many problems: how to make characteristics according to different regions and institutions, how to make foreign language majors serve local construction, and how to integrate training talents with national strategies. These questions need to be pondered over. This paper starts from the era of the gap between foreign talent demand and foreign talent ability, analysis of training foreign language majors of the present mode, mainly from the curriculum system, teaching methods, teaching management and teaching practice to explore how to cultivate the needs of the era of application oriented foreign language professionals, to provide reference for the talents of our country college foreign language professional training model of reform.
\end{abstract}

Index Terms - applied type, foreign language major, talent training model

\section{INTRODUCTION}

China's colleges and universities generally offer English courses from the beginning at the beginning of the twentieth Century, in addition to teaching by the direct method, grammar translation method commonly used. In the late 70s, our country had academic exchanges with major English speaking countries such as Britain, the United States, and more importantly, we understood the teaching theories and practices abroad, and promoted the development of English Teaching in China. From the 80s of last century, the communicative approach was introduced into China and was paid attention to. Foreign language teaching has shifted from emphasizing language knowledge and skills to the cultivation of communicative competence. The employment pressure appeared after the enrollment expansion in the late 90s, which made us realize that the main reason is the lack of professional orientation, training orientation and social needs. Market demand is the vane of talent cultivation. Therefore, some scholars advocate that foreign language majors should not only cultivate students' language skills, but also cultivate students' social practical ability in combination with social needs.

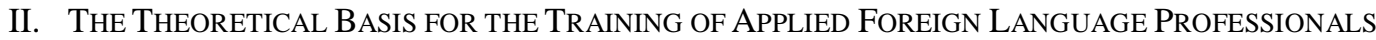

\section{A. Humanism Education Theory}

The humanistic psychology, which began in the middle of the twentieth Century, had a profound influence on its educational thought, purpose, content and way. The contemporary humanistic education thought is represented by Maslow (Abraham Harald Maslow) and Rodgers (Carl. R. Rogers). They are from the theory of human nature, self realization theory, advocate students experience as the center of free learning: highlight the role of emotion in teaching, to know coordination for the emotional power of the new teaching mode of teaching; to improve students "self" as the core, emphasizing the importance of interpersonal relationship in Teaching; teaching focus from the teacher to the students, thinking, emotion and experience of students is the main body of teaching, promote the development of sports teaching individualization, the impact of the traditional theory of education, promote the educational reform. It is also because of the great popularity of humanism that in 70s the "Humanitarianism" became the loudest slogan of the school curriculum reform in the United States.

The humanistic psychologist believes that human beings come from nature, and natural human nature is human nature. Everyone has the ability and motivation to develop his potentiality. Behavior and learning are the products of perception, and most behavior is the result of their own views. Therefore, learning involves the whole person, and the

\footnotetext{
* Funding Sources: Social Science Planning Research Program of Shandong Province (Grant No. 17CWZJ38); Scientific Research Program of Colleges and Universities in Shandong Province (Grant No. J17RA054); Research Program of Young Teachers' Education and Teaching of Shandong Province (Grant No. 16SDJ232); Key Program in Art Science of Shandong Province (Grant No. ZX2015005); Youth and Adolescents Quality Education Work Planning Program of Shandong Province (Grant No. 13AJY090); Scientific Research Program of Jining Medical Univ ersity (Grant No. JY2013RW032); The Visiting Scholar Funded Program of Young Backbone Teachers in Jining Medical University; College Students' Innovative Training Project of Jining Medical University (Grant No. cx2017052); Scientific Research Project of College Students in Jining Medical University (Grant No. JYXS2017RW017)
} 
learning experience can make the learners find their own qualities. From this point of view, learning is "becoming" and becoming a perfect person. The humanistic education theory has a profound guiding significance for the training of applied professionals.

\section{B. Theory of Ability-based Education}

The ability standard produced in the United States in the 1967 is an international popular educational thought and curriculum model, which has replaced the new program of normal education in the traditional discipline. In the 1970s, the idea of competency based education was mature and widely used in vocational education and training in local and other regions, especially in North America. Its biggest characteristic is: the whole teaching goal is how to make the educated have the ability to engage in a certain occupation, and the teaching goal is very specific and targeted (Chen, 2012).

The idea of ability based education is represented by the United States and Canada. "Ability" refers to the knowledge, attitude, experience and feedback related to their own jobs, which constitute special ability, special ability to form comprehensive ability in the form of learning module, and some comprehensive abilities constitute vocational ability (Cheng, 2013). Professional ability includes: professional, method, social ability and so on. This idea was discarded in 1970s. In the mid and late 80s, the vocational education and demand of education based on knowledge and theory were neglected, and the concept of competency based education was revived. It became the leading educational concept of vocational education training reform at the turn of the century. In 1990s, the trend of the ability standard reached the later stage of the prevailing trend. The ability based education determines the training target, teaching content, method and evaluation based on the ability of employment. Emphasis is placed on students' dominant position, and the core is how to make students have practical abilities. The practice of ability based education is different and practice is different.

Competency based initiative advocates people to achieve their social values by giving full play to their professional skills and creativity, which in turn requires the society to create conditions for the development of personal abilities. Ability standard is capacity building, through the development, use and improvement of ability, develop and utilize human potential maximization, make ability to become the core of human capital. This is also the core of the training of Applied Talents - based on the training of students' practical ability (Dai, 2013).

\section{An Analysis of the Status of the Training Mode of ApPliEd Foreign Language Professionals}

\section{A. The Status of the Training Mode of Applied Foreign Language Profession}

The outline of educational planning emphasizes the combination of learning and thinking; advocates heuristic inquiry, discussion and participatory teaching, helps students learn to learn, integrates knowledge and practice, combines teaching with practice, pays attention to teaching students in accordance with their aptitude, pays attention to students' personality differences, and develops their potential strengths. The outline proposed, according to the training target and the talent idea, set up scientific and diverse evaluation standard, perfect comprehensive quality evaluation (Qian, 2009). By summarizing a large number of documents, the present situation of the training of foreign language professionals in Colleges and universities in China is summarized.

(1) To pay attention to the professional scale and ignore the teaching quality and practice. After the enrollment expansion, foreign language education is developing rapidly. Foreign language majors set up the direction of business and tourism. However, there is no relatively perfect training mode that meets the needs of the times. The weak link of practice teaching causes graduates to not meet the needs of the society. Examination oriented education has made many students "high scores and low energy". The basic skills of foreign language majors need to be improved and the quality of teaching needs to be improved.

(2) To innovate the concept of running schools and advocate students as the main body, but the actual teachers are the main ones.At the end of twentieth Century, under the guidance of Some Opinions On Reform professional foreign language education concept of change, but no characteristics, cultivation mode and bigger hindered talent. The essence of "student centered" is to consider the real needs of the students, respect the students' learning personality and characteristics, and cultivate the students' self-learning ability. In the course of teaching, students are advocated as the center to mobilize the initiative of the students, but the reality is that teachers dominate the classroom (Dornyei, 2001).

(3) The mode of talent cultivation is diversified, but it is not scientific. Advocating the consolidation of students' basic skills, although the orientation and elective models are used, it is necessary to be scientific. The emphasis on language basic skills courses leads to low students' humanistic quality. The professional attributes of foreign language and literature determine that language and literature are the core courses, but in the form of Chinese language and literature, the students are lacking in Chinese expression. Therefore, it is necessary to strengthen the construction of the humanities curriculum (Jiang, 2012).

(4) The teaching resources are diversified, but lack of systematization, science and popularization. With the development of science and technology, Internet application has been applied to teaching practice, which greatly expands learning space and teaching methods. However, lacking professional guidance and management in operation, a large number of high-quality teaching and learning resources can not be shared. The teaching materials are mostly theory, light practice, lack of systematic system of knowledge system. The practical practicality of foreign language 
teaching materials is not perfect, which all affect the students' interest in learning and the quality of the training of talents.

(5) The construction of teacher team and the quality of teachers need to be improved. Most foreign language teachers graduate from foreign language linguistics, and do not understand trade, management, law and other professional knowledge, and the teachers who understand these specialties will not be able to speak foreign languages. The "foreign language + profession" sell out in the level of teachers. In addition, most teachers do not study the teaching methods and strategies of scientific teaching simply. These factors have a direct impact on the teaching effect and the quality of personnel training.

\section{B. Based on the Empirical Analysis of the Training Mode of Applied Foreign Language Talents}

Through the investigation, it is concluded that there are the following shortcomings in the training mode of applied foreign language professionals.

(1) Curriculum lacks practical principles (Marion \& Robert, 2011). Curriculum is not a good embodiment of practicality. It is mainly based on general education and professional courses, while practical courses and classes are relatively few, which is the root cause of the lack of practical ability of students. Colleges and universities should pay attention to the cultivation of students' ability and humanistic quality. The key to training talents is to cultivate students' ability and humanistic quality, and to pay attention to the reform of curriculum system to improve the quality of personnel training.

(2) The traditional teaching method is single, and the teaching facilities need to be improved. $91.2 \%$ of the employers are willing to recruit talented people with a certain ability to communicate in a foreign language, especially those with skilled interpretation and translation skills. But the actual teaching methods are mainly teachers, students as the auxiliary form, students do not participate in the right, resulting in students' poor learning. In addition, the old age or shortage of teaching facilities can not meet the students' learning needs. All these have seriously affected the teaching effect and the quality of teaching. The educators should use the teaching method scientifically and rationally, which is the important way and guarantee for the training of applied professionals.

(3)There is little or serious lack in the course of practice teaching. The survey of practical experience of graduates by employers shows that $86.4 \%$ of employers are very interested in explaining the importance of students' practical ability. $65 \%$ of employers pay attention to whether graduates have internships and have relevant work experience, and $80.5 \%$ of units are reluctant to recruit graduates. Practice teaching practice is an indispensable link in the course of teaching, and also a necessary link and bridge for students to enter the society. In fact, there is a serious shortage or shortage of practice class in Colleges and universities, so that students lose the opportunity to apply theoretical knowledge to practice. This is the basic reason why college graduates lack the ability to work.

(4) Teachers' overall level of teaching and scientific research and the quality of 'double teachers' need to be improved. Although the structure of teacher team showed a good momentum of development, but generally less academic leaders, the lack of well-known experts and scholars, the number of senior professional titles is relatively low, most of the teachers' professional knowledge is unitary, lack of application of related background knowledge and practical experience, scientific research should be geared to the needs of application, service consciousness in regional economic and social development needs to be improved. The scientific research phenomenon of professional title is very serious. The incentive mechanism of scientific research to promote professional construction and improve the quality of teaching still needs to be improved. All these are serious defects in the training of applied foreign language professionals.

(5) The training of talents is in serious disconnection with the needs of the society. Personnel training only exists in the education system, not social and economic development of the country, science and technology, demand hook, resulting in much graduates, but can really meet the needs of the community are few, which is caused by the large number of graduates working pressure of the root. In addition, Chinese and foreign cooperative schools have developed rapidly, but the demand for talent is still lagging behind the development of the times. The international space for running a school needs to be further expanded, and the international exchanges and cooperation in the deep and wide fields need to be further promoted and strengthened.

In summary, the present foreign language Chinese Local Colleges of professional personnel training problems focused on: 1) the curriculum is not perfect; 2) teaching methods need to be improved; 3) professional size, light quality of teaching and practice; 4) personnel training mode is diversified, but not scientific; 5) advocate students mainly, but the actual by teachers; 6) teachers team construction and the quality of teachers needs to reform and to promote the. The practical communicative function of foreign language is becoming more and more prominent in terms of the requirements of foreign language skills and the employment recruitment. It is imperative to reform the curriculum and the training program of professional talents for the needs analysis and guidance of the society.

\section{Guiding IdEOlogy ANd Training ObJectives For the Training Mode OF ApPliEd Foreign LANGUAGE PROFESSIONALS}

College English Teaching Syllabus for English Majors' pointed out that higher education goal is to cultivate English majors with solid English language foundation and extensive cultural knowledge, proficient in English in foreign affairs, 
education, trade, culture, science and technology, military departments engaged in translation, teaching, management and research work of Compound English talents. According to their own development, teachers, students, social and economic development and market demand of regional universities, according to local conditions, because the school system, independently determine the training mode of English majors. Changing educational ideas and renewing educational ideas is the practice of teaching reform, and it is the ideological basis and guide of cultivating applied talents. Therefore, the training of applied talents must break through the traditional knowledge and practice, broaden the field of personnel training, enhance practical teaching, and cultivate practical talents with solid theoretical foundation and strong practical ability.

Talent is the first resource of social development and an important driving force for social progress. In order to play a better role in promoting talents, the specifications of talents must meet the needs of social development. The construction of talent training mode should follow the rule of higher education, take market demand as the guidance, and rely on local government to build a discipline and professional system serving local economic and social development. We should adhere to the orientation of "local, applied and professional" (Shen, 2013). Focusing on the coordinated development of knowledge, ability and quality of applied talents, focusing on ability training, we should pay attention to students' cognitive and practical ability and innovative spirit, so that students' professional knowledge is extensive, practical ability is strong, and their comprehensive quality is high. The spirit of renewing the concept of talent training is in line with The Outline to update the concept of talent cultivation, innovative personnel training mode; pay attention to the combination of learning and thinking, in advocating heuristic based teaching, teaching students to learn; focus on learning; students, establish a diversified It differs from man to man.; talent; respect for personal choice, encourage the development of personality, not sticking to formalities training applied talents of social needs (Qian \& Xu, 2007).

Professor Wenzhong $\mathrm{Hu}$ (2009) pointed out that despite the various problems in the process of experiment, whether foreign language departments in specialized foreign languages universities, science universities or comprehensive universities have explored the practice of training foreign language talents according to their own characteristics. To determine the training objectives, choose application or professional direction must be forward-looking, emphasizing the demand analysis, considering the local social and economic development, to meet the requirements of the market economy, a serious argument planning, considering the difference of different types of colleges and universities, because the school system, develop training mode from the needs of their respective disciplines, professional development, local development. In short, the goal orientation of English professional training should respect the needs of the society and students themselves. Considering the regional and school conditions, we must also ensure the quality and strength of talents in the training of applied talents ( $\mathrm{Su}, 2004)$.

According to Teaching Program, the surveyed colleges and universities have the general goal of training professional talents: cultivating solid foundation, professional skills, strong ability, humanities literacy and scientific literacy, innovative and applied high-level professionals. Over the years, we have adhered to the school running policy of "stabilizing scale, optimizing structure, improving quality, highlighting characteristics and strengthening services" and adhering to the development strategy of "quality-based school, talent and school building" (Su \& Zhuang, 2008), and adhering to the talent cultivation as the fundamental task in teaching as the center, facing the demand of social development, cultivating applied talents. Adhere to the general education and special education system, combining knowledge education and practice ability, combined with comprehensive quality education and professional skills education and training applied talents with society as the goal, on deepening the new training mode of applied talents, promote the deepening reform of education and teaching.

The adjustment mainly reflected in: to meet the needs of society as the goal, to strengthen the training of applied talents, outstanding talent training according to the social demand to set up professional direction; professional direction of curriculum system is complete, timely updates; both the importance of scientific knowledge, pay more attention to the cultivation of ability and quality; respect for the law of discipline, the moderate change education ideas and methods bold innovation, outstanding professional features (Wang, 2009). Because the construction of college is: the characteristics of survival, deepen the connotation construction, adhere to the dislocation development, emphasizing the application first, practice education, the professional development path of 'foreign language specialty, foreign language professional direction', to cultivate "two in one" high-quality applied foreign language talents.

\section{The Construction of the Training Mode of Applied Foreign Language Professionals}

The teaching concept of "taking students as the main body, taking teachers as the dominant factor, relying on cooperation forms, focusing on curriculum construction, focusing on practical teaching and actively exploring classroom reform" has been put forward by the surveyed universities. The key to talent training is the formulation of the talent training program, and the core of the talent training program is the specialty curriculum system. It is an urgent task for the foreign language major of local universities to construct a scientific and reasonable and characteristic curriculum system. As Xianyu Yang (2011) put forward from the "school standard" starting to determine the goal of talent training, according to the type of school, development history and teachers' situation, we should rationally select the goal and mode of personnel training, highlighting the characteristics of personnel training. The following four aspects are mainly constructed from the curriculum system, teaching methods, teaching management and practical 
teaching.

\section{A. Curriculum System}

(1) To broaden the professional caliber and integrate the curriculum resources. Pay attention to various courses in coordination with the overall advantage to play the curriculum system, the curriculum system, teaching content optimization, reasonable research ability, to adapt to the society wide as the basic guiding ideology of curriculum construction. To rely on the comprehensive advantages of running schools, the society for talents actual demand, the ability of language and language skills training as the main line, to lay a solid foundation, to broaden the caliber, outstanding application.

(2) To abandon the old curriculum and add new curriculum for social needs. The proportion of the basic, professional and practical classes should be rationally divided. It is scientific, feasible and adaptive to build a curriculum system based on application, practicality and ability. It takes student's social adaptability and recognition degree as an important index of curriculum evaluation. On the basis of deepening foreign language knowledge and skills of learning and practice, to carry out extensive trade, foreign affairs, finance, education, legal and other professional knowledge and skills of learning, to cultivate students' ability of theory with practice and flexible use of language skills to solve related problems ability, construction of foreign language + education, business + foreign language ,foreign + tourism education, shunt interdisciplinary curriculum system, cultivate proficient in foreign languages and master relevant professional knowledge, familiar with Chinese culture and the international practice of the high-quality applied talents of foreign languages.

(3) To set up the course content of "learning to use". The role of classroom teaching is to cultivate students' interest, to provide appropriate language input, to cultivate students' learning strategies and to provide guidance for students' extracurricular learning. According to the principle of openness and flexibility, we should combine professional and general knowledge, compulsory and elective courses, break the barriers of disciplines, strengthen the connection and integration of curriculum and curriculum system, infiltrate the interdisciplinary knowledge into the curriculum, and enable students to learn the connotation of knowledge in a wide range of fields. It also accords with the pragmatism represented by Dewey, emphasizing the training of thinking ability, self-learning ability and basic living ability, which is emphasized in teaching value. The practical feature is to attach importance to interest, vitality, initiative and cooperation between people and people.

(4) The curriculum system that advocates science and humanities, both theory and practice. General talents with strong basic knowledge and humanistic quality and skilled talents are not fragmented. We should consider the professionalism and professionalism to train qualified talents who are suitable for the society and have comprehensive qualities. With the guidance of the students' employment, the platform module curriculum system is perfected. We must compress compulsory courses, increase elective courses, and energetically strengthen the number, duration and credits of practical teaching. In order to improve the teaching level and improve the quality of talent training, we should focus on the construction of excellent courses and key courses.

(5) To compile the teaching materials in accordance with the actual needs. Teaching material is an important part of teaching reform. Reasonable selection and use of textbooks do not stick to specific teaching materials. According to teaching requirements and students' needs, we should make bold decisions on teaching materials, supplement a large number of materials outside teaching materials, and meet students' learning needs. This paper studies the problems in the use of teaching materials, and combines teaching experience to adjust the content of students' skills.

\section{B. Teaching Methods}

The foreign language college reforms the teaching methods and means to explore the individualized and diversified teaching with the premise of respecting the development of students' personality. In combination with practical experience, students should be encouraged to study independently and cooperate with each other, and to cultivate the students' ability to explore and the spirit of innovation.

(1) "Cooperative" way of learning. The students in small groups for mutual learning, to stimulate students' interest in learning, to provide students with more opportunities to practice and communication, to ensure the students' autonomous learning; improve classroom atmosphere, improve student achievement; cultivate students' cooperation consciousness and team spirit, to achieve the effects of class, is considered to be the successful teaching mode to promote.

(2) "Student - centered, teacher - oriented" multiple interaction teaching mode. Teachers should understand their students as independent individuals and try to put themselves in a position to understand their views on the world, rather than to impose their views on their students. Not only imparting language knowledge and skills, but also paying attention to the ability of language use, self-learning ability and innovation ability. Through the design of targeted teaching, students are encouraged to participate in the classroom actively. By increasing the amount of reading and cultivating the sense of language, the writing skills will be promoted. More foreign language practice platform is provided to improve the students' ability to apply foreign languages in a comprehensive way.

(3) To strengthen the main course, grade teaching, and promote the training of language skills. Improving students' language skills is the key to the training of applied foreign language talents. Through teacher guidance students' independent way, mobilize the enthusiasm of the students and do well in the training and assessment of language skills. 
From the actual needs of the talent market, professional and interdisciplinary courses have been added.

(4) To construct the " $1+1+\mathrm{N} "$ second classroom education system and network teaching. With the support of network technology, teaching is not limited by time and place. It pays attention to the combination of practicality, knowledge and interest, and develops towards the direction of self-directed learning. It turns the "teacher-centered" classroom teaching mode into the modern teaching mode. To constructing a "1+1+N" second classroom education system with rich content and various forms to cultivate students' professional ability and self-learning ability.

(5) To attach importance to international exchanges and cooperation. Not regularly invite experts from home and abroad to give a lecture.

(6) To strengthen the cooperation between school and enterprise, realize the docking of teaching and demand, and expand the practical training base. Invite the enterprises and enterprises to practice the experienced experts of e-commerce, foreign trade and other experts into the classroom to promote cooperation and education and improve the teaching effect. To build a new internship base and organize various training activities regularly. Enterprises and enterprises are invited to offer suggestions on how to cultivate applied professionals.

\section{Teaching Management}

The daily teaching management system is to maintain the normal order of teaching and make the rules and regulations of the normal operation of the teaching process.

(1) To carry out the credit system, set up the elective course in the hospital, and improve the form and content of the examination. According to the nature and characteristics of the course, it is developed from a single written test to closed, open, written and oral test, oral examination, and net examination. The proportion of the average achievement was increased from $30 \%$ to $50 \%$. The proportion of the main and objective questions in the examination is about 6:4, which strengthens the importance of students' autonomous learning.

(2) To implement the network evaluation model of promoting learning, training and teaching, and emphasizing the combination of learning practice, encourage the students to have "one diploma and many certificates", organize and arrange professional pass examinations, business English related qualification and grade examination and so on. In order to cultivate students' comprehensive language use ability and autonomous learning ability, based on the item bank and test paper database, with the help of intelligence and interaction function of network devices, some web courses are applied to some courses. Unit, special skills, grading, mid-term and final examinations, giving full play to evaluation, diagnosis, guidance and motivation in teaching, improving students' learning efficiency and improving teaching quality.

(3) To improve the teaching quality monitoring and evaluation system. The combination of formative assessment and terminative assessment, traditional evaluation and network evaluation, special evaluation combined with term comprehensive evaluation, self-evaluation of teachers and students, mutual evaluation of teachers and students, and combination of leadership evaluation and peer evaluation. Clear quality standards, improve relevant rules and regulations and teaching evaluation system, and improve the quality assurance system for internal teaching (Wen \& Xu, 2011). We should optimize the teaching evaluation index and evaluation method, pay attention to the evaluation of students' learning effect and the use rate of teaching resources, and improve the mechanism of result feedback and teaching improvement.

(4) To strengthen the function of culture and educating people. To carry out such as "FLTRP Cup" speech contest, poetry, songs, writing words, rich and colorful various academic competitions, throughout the school year, the combination of inside and outside class language practice, motivate students, cultivate students' comprehensive ability of using language (Yan, 2009).

(5) To strengthen the construction of 'Double Teachers' teaching staff. Teachers undertake the task of transferring teaching content to students, and the quality of teachers directly affects the quality of teaching. We should actively improve the combination of teachers' team, and try to form a virtuous teaching cycle of "teaching with teaching and studying with research and promoting teaching".

\section{Practice Teaching}

The cultivation of theoretical knowledge and practical ability is the comprehensive cultivation of the quality of talents. The traditional practice teaching and theory are disjointed, and the students' application ability can not be trained. Social practice is the test and acceptance of the teaching process and can not repair the results of the teaching. Professor Hu Wenzhong for the training mission in new period put forward: English majors should return the discipline standard, to find a balance between humanistic education and skills training; training elite talents; training of thinking students' research ability; compressed language skills training, the technology can be combined with the content.

The content of practice and theory course can be divided into: professional skills practical courses, professional practice courses, experimental practice courses and graduation design practice courses. The specific implementation measures are as follows:

(1) To improve the practical teaching facilities and to build a practical teaching system as the core, and to strengthen the training of students' practical ability. A curriculum system should be constructed as the core of the practical teaching to strengthen the training of students' practical ability. Such as: to increase the content of English Majors' skills training, and to integrate with the acquisition of innovative credits and activities.

(2) To consolidate the professional foundation and strengthen the practical skills. Professional skills training should 
be carried out for four years, focusing on training listening, speaking, reading and writing and practical skills. For example, it pays attention to the students' book, simple strokes, classroom language, courseware making and so on, and puts the examination results into the comprehensive evaluation of the students and the content of the evaluation of the innovation credits. The curriculum system of practical teaching is constructed and embodied by both in and out of the class. In class practice, there are skills, practical speech and intensive training of professional examinations, such as simulated interpretation, business negotiation, foreign trade practice, translation, practice training and practice of internship.

(3) To do a good job in all aspects of practical teaching and strengthen the construction of practical training bases. Based on the teachers' Education Alliance, the educational practice mode of basic education and school-based teaching connection and mutual promotion of study and research are constructed. Through strengthening the practical teaching link, the students' ability to analyze and solve problems and the ability of innovation are trained to improve their comprehensive quality.

(4) To implement the "double campus language practice model". In order to adapt to the trend of the internationalization of higher education in twenty-first Century, we should cultivate applied foreign language talents with international vision and realize the sharing of teaching resources. According to the foreign language syllabus, the reform of teaching mode, examination content and mode has been promoted. We should renew teaching contents, improve teaching methods, combine learning both inside and outside class, combine compulsory courses with elective courses, expand knowledge and skills training to improve students' foreign language level (Zhong, 2013). In order to enhance teachers' occupation literacy as the foundation, in order to improve the quality of teaching as the basis, to update the teaching contents, improving teaching methods, optimizing skills training as the main line, a firm direction, implement the plan, to ensure effectiveness, steadily improve the quality of teaching, accelerate the construction of the application oriented university characteristics.

\section{CONCLUSION}

Under the background of China's current higher education reform and development, how to reform, innovate and keep pace with the development of foreign language education in Colleges and universities has become a hot topic for educators, and it is also one of the problems to be solved in higher education. Under the impetus of reform, China's foreign language majors in Colleges and universities are facing rapid development. They also face problems of reform and implementation in discipline construction, discipline characteristics, curriculum setting and personnel training. Among them, the reform of talent training mode is the core of the teaching reform of foreign language majors. To this end, the domestic scholars are also actively exploring to offer suggestions for the reform of teaching.

On the basis of the domestic and foreign research experience, based on humanism and competency based education theories, combined with the new educational concept, the actual characteristics of local colleges and universities multiple perspectives for the research on the training mode of applied talents, this paper follow the following principles: (1) The research process of the system. Around the core issues of talent cultivation, such as training objectives, training specifications, curriculum design, teaching methods, teaching practice, assessment management, teaching staff and so on. (2) Research and embodiment of the new education concept. The goal of applied foreign language talents training is to cultivate language application ability, enable students to communicate skillfully in foreign languages after graduation, and enhance their self-learning ability and comprehensive cultural quality in order to meet the needs of economic development and international communication. Applied foreign language professionals must have a good ability to communicate in foreign languages, language knowledge and application and intercultural communication. (3) The research pays attention to scientific and practical. With the guidance of educational theory, market demand oriented, scientific data analysis as the basis, combined with the research of our school, it is closely related to the construction of the subject. (4) Research and national strategic docking. The study of characteristic foreign language strategy can provide new ideas for the training of foreign language professionals.

From the perspective of social demand for talents, we should cultivate applied talents in foreign languages, not only considering the number of talents, but also how to better improve the quality of talents.

From the combination of theory and Practice Research on the personnel training mode of talents, demand analysis, application of language major talents should possess, especially to practice the ability to integrate and analysis, and to construct the personnel training plan according to training goals. Therefore, in the future work, we will further explore and analyze the needs of applied foreign language professionals and how to cultivate core competencies of talents.

The research of personnel training cannot be stereotyped. Based on the reality of colleges and universities, local economic development and national strategy, we should explore and study the characteristics of the local conditions, the characteristics and the actual effect, and seek for a unique and practical talent training mode.

\section{REFERENCES}

[1] Chen, X. Y. (2012). Curriculum and Teaching Theory. Beijing: Publishing and publishing of Higher Education.

[2] Cheng, X. T. (2013). "On the Problem of Where Foreign Language Majors Go From.” Shandong Foreign Languages Teaching Journal. (2): 75-78.

[3] Dai, W. D. (2013). “Orientation, Layout and Development of Foreign Language Education in China." Contemporary Foreign 
Language Research. (1): 11-16.

[4] Dornyei, Z. (2001). Teaching and Researching Motivation. Harlow: Longman.

[5] Hu, W. Z. (2009). Foreign Language Teaching and Research. Beijing: Foreign Language Teaching and Research Press.

[6] Jiang, S. P. (2012). "Research on the Training Mode of Foreign Language Majors in Teaching-Oriented Universities." Personnel Training. (3): 99-102.

[7] Marion, W. \& L. B. Robert. (2011). Psychology for Language Teachers A Social Constructivist Approach. Cambridge: Cambridge University Press.

[8] Qian, G. Y. \& L. Q. Xu. (2007). The Transformation of Higher Education and the Training of Applied Undergraduate Talents. Hangzhou: Zhejiang University Press.

[9] Qian, G. Y. (2009). Education Innovation and the Cultivation of Applied Innovative Talents. Hangzhou: Zhejiang University Press.

[10] Shen, Y. (2013). "How to Cultivate Applied Foreign Language Talents in the Era?" Adult Education in China. (1): 12-15.

[11] Su, D. F. (2004). Foreign Language Teaching Reform: Problems and Countermeasures. Shanghai: Shanghai Foreign Languages Education Press.

[12] Su, D. F. \& Z. X. Zhuang. (2008). Theory, Practice and Method of Modern Foreign Language Teaching. Shanghai: Shanghai Foreign Languages Education Press.

[13] Wang, Q. (2009). The Methodology of English Teaching. Beijing: Foreign Language Teaching and Research Press.

[14] Wen, Q. F. \& H. Xu. (2011). Annual Report on Foreign Language Education in China. Beijing: Foreign Language Teaching and Research Press.

[15] Yan, M. (2009). A Research on the Theory and Practice of ESP in College English Teaching. Harbin: Heilongjiang University press.

[16] Zhong, B. L. (2013). "University Personnel Training Should Study New Problems and Meet New Challenges." Chinese University Teaching. (1): 21-25.

Yuan Kong received her M.A. degree in linguistics. She is currently a lecturer at the School of Foreign Languages, Jining Medical University, Jining, Shandong, China. She teaches various subjects including: English intensive reading, English extensive reading, listening, nursing reading and so on. Her research interests mainly include English language teaching, applied lingu istics, cross-cultural communication, etc. 